\title{
Length-Weight Relationships of Paraphanius similis in Mamasın and Seyhan Reservoirs (Turkey)
}

\author{
Irmak KURTUL ${ }^{1 *}$, Hasan M. SARI ${ }^{2}$
}

\begin{abstract}
The length-weight relationship of Paraphanius similis in the Mamasin (Aksaray) and Seyhan (Adana) reservoirs were studied on the basis of $n=193$ fish specimens $\left(n_{\text {females }}=85 ; n_{\text {males }}=108\right)$. Fish samples were collected using seine net net in 2016 year. The length-weight relationship was found as $\mathrm{W}=0.011 \mathrm{~L}^{3.589}(\mathrm{r}=0.982)$ for females and $\mathrm{W}=0.015 \mathrm{~L}^{3.406}$ $(\mathrm{r}=0.939)$ for males in Mamasin Reservoir; it was found as $\mathrm{W}=0.017 \mathrm{~L}^{3.083}(\mathrm{r}=0.980)$ for females and $\mathrm{W}=0.008 \mathrm{~L}^{3.725}$ $(r=0.974)$ for males in Seyhan Reserovir. The present study considers the first record and comprehensive information on the length-weight relationship of $P$. similis in the Mamasin Reservoir. The results of this study might support to the conservation of this species and contribute the knowledge on its ecology and biology.
\end{abstract}

Keywords: Endemic species, freshwater fishes, killifish, Cyprinodontidae.

\section{Mamasın ve Seyhan Barajlarında Dağılım Gösteren Paraphanius similis’in Boy- Ağırlık İlişkisi (Türkiye)}

Öz

Mamasın (Aksaray) ve Seyhan (Adana) barajlarındaki Paraphanius similis türünün boy-ağırlık ilişkisi n=193 ( $\mathrm{n}_{\text {diși }}=85$; $\mathrm{n}_{\text {erkek }}=108$ ) balık ölçümü yapılarak incelenmiştir. Balık örnekleri 2016 yılında ığrıp kullanılarak toplanmıştır. Boy-ağırlık ilişkisi Mamasın Barajı'ndaki dişi bireyler için W=0.011 L ${ }^{3.589}(r=0.982)$ olarak, erkek bireyler için $\mathrm{W}^{2}=0.015 \mathrm{~L}^{3.406}$ ( $r=0.939)$ olarak; Seyhan Barajı'ndaki dişi bireyler için $\mathrm{W}=0.017 \mathrm{~L}^{3.083}$ ( $\left.\mathrm{r}=0.980\right)$ olarak; erkek bireyler için $\mathrm{W}=0.008 \mathrm{~L}^{3.725}$ ( $\left.\mathrm{r}=0.974\right)$ olarak bulunmuştur. Bu çalışma, $P$. similis'in Mamasın Barajı'nda kaydı verilen ve türün oradaki boy-ağırlık ilişkisi hakkında bilgi içeren ilk çalışmadır. Çalışmanın sonuçlarının türün ekolojisi ve biyolojisi hakkında bilgi sahibi olunmasına katkıda bulunması ve türün azalmakta olan popülasyonunun korunmasını desteklemesi beklenmektedir.

Anahtar Kelimeler: Endemik türler, tatlısu balığı, dişli sazancık, Cyprinodontidae.

\footnotetext{
${ }^{1}$ Ege University, Faculty of Fisheries, Marine and Inland Waters Sciences and Technology Department İzmir, Turkey, irmak.kurtul@gmail.com

${ }^{2}$ Ege University, Faculty of Fisheries, Marine and Inland Waters Sciences and Technology Department İzmir, Turkey, hasan.sari@ege.edu.tr

${ }^{1}$ https://orcid.org/0000-0002-3566-9172 2 https://orcid.org/0000-0003-1000-514X
} 


\section{Introduction}

Aphanius genus belong to the Cyprinodontidae fish family. Distinctly the other species of the family which are native to America, Aphanius species are native to southern Europe, southwestern Asia and northern Africa. Some of the species in the genus are microendemic species and live in to only a very small region.

Aphanius is a very rich genus with most of the identified species endemic to Turkey (Kosswig, 1955; Wildekamp et al., 1999; Yoğurtçuoğlu and Ekmekçi, 2013). The genus Aphanius have more than 20 species which are distributed along the ancient coast of the Tethys Sea (Kosswig, 1955; Villwock and Franz, 1972; Wildekamp et al., 1999). Aphanius members are Cyprinodontiform fishes and their distribution has also been effected by glacial period and interglacial period differences in the Mediterranean Sea (Wildekamp et al., 1999).

There are many study about the species and subspecies of the genus Aphanius in Turkey (Wildekamp et al., 1999). Molecular phylogeny and biogeograpy of the Aphanius genus have been searched (Hrbek et al., 2002). There is a comprehensive study about their genetic relationships between Anatolian species and subspecies of Aphanius (Bardakçı et al., 2004; Hrbek and Meyer, 2003). There is a study about on their population and growth features of A. anatoliae (Güçlü et al., 2007). Morover there is a study for a new genetic structure of the killifish family Aphaniidae, with the description of A. teimorii (Freyhof and Yoğurtçuoğlu, 2020).

The genus Aphanius has an important genus for fish biodiversity but it has no economic importance. According to the IUCN Red List, some of the genus members are seriously threatened. In addition, some of the species of this genus uses for aquariums and also they are using in laboratory studies (Güçlü, 2003; Sezen, 2011).

Paraphanius similis (namely Aphanius mento) distributes in shallow freshwater close to vegetation. They feed on crustaceans, insect larvae, algae and breeds during the warmer months of the year (Krupp and Schneider, 1989). They are subtropical species and they live in $10-25^{\circ} \mathrm{C}$ (Baensch and Riehl, 1985). Reproduction period of the species is from May to July (Güçlü, 2003; Küçük and İkiz, 2004). In reproduction period, the color of male specimens are dark blue or navy-blue, while females are gray, brown or green. Their maximum length is $5 \mathrm{~cm}$ (Huber, 1996). They can easily maintain in the aquarium (Huber, 1996).

They spread in the southeast and west of Iraq, in the north of the Arabian Peninsula, Syria, in the coastal river systems in Lebanon, Syria and Israel (Wildekamp, 1993). In Turkey, they were recorded in Seyhan and Ceyhan rivers (in Elbistan District), the branches of the Firat River, Kirkgöz Spring (Antalya), Aksu Stream (Antalya), Yeşilada (Samandağ) and Akgöl (Konya) lakes (Güçlü, 2003). 
In the literature, there are many studies about on $P$. similis which are focusing on their systematic features, morphologic characters, growth parameters, feeding, reproduction characters and their embryological and larval development periods (Wildekamp et al., 1999; Güçlü and Küçük, 2008; Sezen, 2011; Güçlü and Küçük, 2011; Alagöz Erguden, 2015).

The field area of the present study were Mamasin and Seyhan reservoirs. Mamasin Reservoir

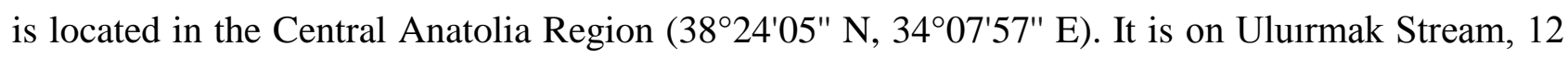
km east of Aksaray (Gücünkaya) and it uses for the purpose of irrigation. Seyhan Reservoir is located in Mediterranean Region of southern Turkey (3702'56" N, 35²18'54" E). It is 15 km above Adana (Çukurova) and it is a reservoir built to save Adana from the flood caused by the Seyhan River. The reservoir shows typical Mediterranean climate characteristics with considerable seasonal variation.

P. similis was reported as A. mento for the first time in 2005 in the Seyhan Reservoir (Alagöz Ergüden and Göksu, 2012) and a study provided the information on their population structure (Ergüden, 2020). However, there is no previous data or length-weight relationship (LWRs) records were available for $P$. similis for Mamasin Reservoir.

The aim of the present paper was to present the LWRs for two Aphanius from two reservoirs in Turkey. The present study considers the length-weight relationships of $P$. similis for Mamasin Reservoir first time.

LWRs are essential data for biodiversity of fishes and fisheries management. It is using different types of fishery researchs. The data of LWRs is notable for understanding the actual situation of the fish stock (Petrakis and Stergiou, 1995). In addition to, the data enable comparisons between populations of the species living in different ecosystems (Sangun et al., 2007). These data provide to compare the characteristics of the fish populations (Moutopoulos and Stergiou, 2002).

\section{Materials and Methods}

\subsection{Study area and sampling}

Fish specimens (Figure 1) were captured by seine net from two different localities Mamasin and Seyhan reservoirs in 2016 year (in May) then preserved in a 5\% formaldehyde solution and transported to the laboratory for later examination. In sex determination external coloration of the individuals were checked. Identification of the specimens was achieved according to literature (Wildekamp et al., 1999; Hrbek and Wildekamp 2003; Pfleiderer et al., 2014; Freyhof and Yoğurtçuoğlu, 2020). 


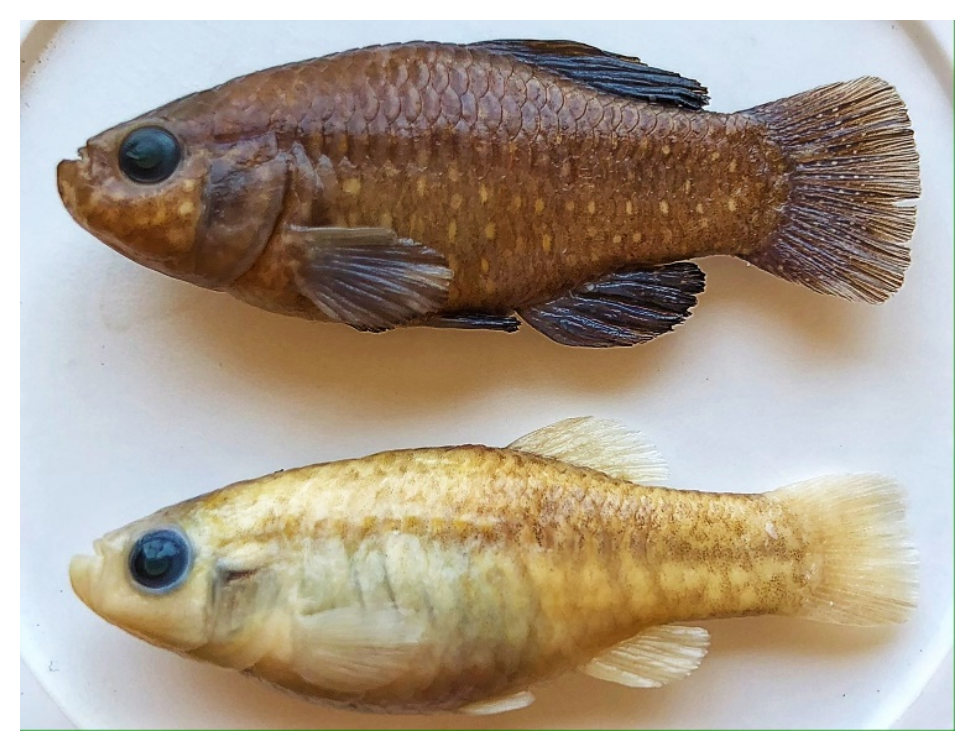

Figure 1. Male (top) and female specimens of Paraphanius similis in Mamasin Reservoir (samples preserved in formaldehide).

\subsection{Data analyses}

The total length (L) of each $P$. similis specimen was measured with a vernier caliper to the nearest $0.05 \mathrm{~mm}$, and weighed with a digital scale to the nearest $0.01 \mathrm{~g}$. specimens. The correlation coefficient was calculated (Zar, 1999) and a correlation coefficient significance control test was applied. The equation $\mathrm{W}=\mathrm{aL}^{\mathrm{b}}$ was used to put forth the LWRs in the study (Ricker, 1973). In the equation, $W$ is the total weight (g), $L$ is the total length (cm), and $a$ (intercept) and $b$ (slope) are regression constants (Zar, 1999). Standard error of the constants $a$ and $b$ were estimated. The student t-test was used to determine the growth types for the female and male specimens according to their localities (Pajuelo and Lorenzo, 1998).

\section{Results and Discussion}

\subsection{Length and weight distribution}

Due to the sexual dimorphism in P. similis, the LWRs parameters were calculated separately for the female and male specimens. A total of 106 P. similis were measured in Mamasin Reservoir and a total of 87 P. similis were measured in Seyhan Reservoir for determining their lenth and weight distribution and their LWRs. P. similis specimens length and weight distribution and their standard error according to the sexes were given below for the study areas Mamasin and Seyhan reservoirs (Table 1). 
Table 1. The length and weight distribution, mean length and weight and their standard errors of $P$. similis in Mamasin and Seyhan reservoirs.

\begin{tabular}{lllrrrrrr}
\hline \hline Locality & Sex & $\mathbf{n}$ & $\mathbf{L}_{\min }$ & $\mathbf{L}_{\max }$ & $\mathbf{L}_{\operatorname{mean}} \pm \mathbf{S E}$ & $\mathbf{W}_{\min }$ & $\mathbf{W}_{\max }$ & $\mathbf{W}_{\text {mean }} \pm \mathbf{S E}$ \\
\hline \hline Mamasin Reservoir & $\mathrm{F}$ & 31 & 3.3 & 5.2 & $4.40 \pm 0.557$ & 0.73 & 3.77 & $2.35 \pm 0.924$ \\
& $\mathrm{M}$ & 75 & 3.2 & 5.0 & $4.56 \pm 0.277$ & 0.77 & 3.56 & $2.74 \pm 0.515$ \\
Seyhan Reservoir & $\mathrm{F}$ & 54 & 2.7 & 4.5 & $3.42 \pm 0.401$ & 0.39 & 1.71 & $0.79 \pm 0.314$ \\
& $\mathrm{M}$ & 33 & 2.3 & 3.8 & $2.92 \pm 0.385$ & 0.20 & 1.30 & $0.50 \pm 0.256$ \\
\hline \hline
\end{tabular}

The mean length of the females and males were found as $4.40 \mathrm{~cm}, 4.56 \mathrm{~cm}$; the mean weight of the females and males were found as $2.35 \mathrm{~g}, 2.74 \mathrm{~g}$ in Mamasin Reservoir, respectively.

The mean length of the females and males were found as $3.42 \mathrm{~cm}, 2.92 \mathrm{~cm}$ in Seyhan Reservoir. The mean weight of the females and males were found as $0.79 \mathrm{~g}, 0.50 \mathrm{~g}$ in the same study area. According to the study results Mamasin Reservoirs member's mean total length and mean weight were found bigger than the Seyhan Reservoirs. Since the sampling season is the same in both researching area (in May), the reasons for this difference could be thought due to food sources or competition with the other species in the habitats. In the sampling period, Gambusia holbrooki were detected in the Seyhan Reservoir with $P$. similis, however there was no other species in the sampling in Mamasın Reservoir.

\subsection{Length-weight relationships}

The sample size (n), estimated parameters of the LWRs ( $a$ and $b$ ), coefficient of regressions, standard error of $a, b, r$, t-test results and growth types are given in Table 2.

Table 2. LWRs parameters of $P$. similis are given for Mamasin and Seyhan reservoirs.

\begin{tabular}{|c|c|c|c|c|c|c|c|c|c|c|}
\hline Reservoir & Sex & $\mathbf{n}$ & $\mathbf{a}$ & $\mathrm{SE}_{\mathbf{a}}$ & b & $\mathrm{SE}_{\mathbf{b}}$ & $\mathbf{r}$ & $\mathrm{SE}_{\mathbf{r}}$ & $\mathbf{t}_{\text {test }}$ & GT \\
\hline \multirow[t]{2}{*}{ Mamasın } & $\mathrm{F}$ & 31 & 0.011 & 0.002 & 3.589 & 0.128 & 0.982 & 0.093 & $\mathrm{t}_{\mathrm{cal}}=4.601>\mathrm{t}_{0.05, \mathrm{n}=31}=2.03$ & $\mathrm{~A}(+)$ \\
\hline & $\mathrm{M}$ & 75 & 0.015 & 0.003 & 3.406 & 0.087 & 0.939 & 0.082 & $\mathrm{t}_{\mathrm{cal}}=4.666>\mathrm{t}_{0.05, \mathrm{n}=75}=1.99$ & $A(+)$ \\
\hline \multirow[t]{2}{*}{ Seyhan } & $\mathrm{F}$ & 54 & 0.017 & 0.002 & 3.083 & 0.087 & 0.980 & 0.073 & $\mathrm{t}_{\mathrm{cal}}=0.954<\mathrm{t}_{0.05, \mathrm{n}=54}=2.00$ & $\mathrm{I}$ \\
\hline & M & 33 & 0.008 & 0.001 & 3.725 & 0.157 & 0.974 & 0.116 & $\mathrm{t}_{\mathrm{cal}}=4.617>\mathrm{t}_{0.05, \mathrm{n}=33}=2.03$ & $\mathrm{~A}(+)$ \\
\hline
\end{tabular}

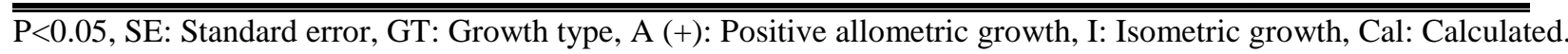

P. similis specimens correlation coefficient, $\mathrm{r}=0.982$ and $\mathrm{r}=0.939$ in Mamasin Reservoir for females and males, respectively. Similarly, in Seyhan Reservoir r=0.980 and r=0.974 in females and males. The correlation coefficient results in both study area showed that they are highly correlated.

The $b$ constant typically close to three, therewithal it has a value between two and four. A value of three, shows that the fish grows symmetrically or isometrically; other values indicate fish has an allometric growth (growth type might be positive or negative) (Tesch, 1971). 
In the current study, positive allometric growth were found in females and males in Mamasin Reservoir. Similarly, positive allometric growth were found in males in Seyhan Reservoir, distinctly isometric growth type were found in females. It was exposed that the Seyhan Reservoir's females had smaller $b$ constant than the Mamasin Reservoir's females. The main reason of this situation might be the annual temperature differences between the cities. Cause of the higher annual temperature in Adana, the Seyhan Reservoir's females might be had reproduced before than Aksaray and might be weight loss after reproduction.

Comparison of the LWRs between the present study area results and other studies are shown in Table 3. The range of $r$ and $b$ parameters of the present study showed similarity in some localities. Constant $b$ varied between 2.225-3.589 and 2.403-3.725 for the females and males, respectively, in terms of location. The highest $b$ constant were found as 3.725 in this study for males in Seyhan Reservoir.

Table 3. LWRs parameters of the Aphanius species in the other studies.

\begin{tabular}{|c|c|c|c|c|c|c|}
\hline Locality & Species & Sex & $\overline{\mathbf{n}}$ & 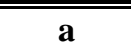 & $\overline{\mathbf{b}}$ & 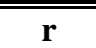 \\
\hline $\begin{array}{l}\text { Küçükçekmece Lagoon, İstanbul (Tarkan et al. } \\
\text { 2006) }\end{array}$ & A. fasciatus & $\overline{F+M}$ & 11 & 0.01820 & 2.940 & 0.909 \\
\hline Lake Eğirdir, Isparta (Güçlü, 2012) & A. anatoliae & $\mathrm{F}+\mathrm{M}$ & 522 & 0.0232 & 2.322 & 0.826 \\
\hline \multirow{2}{*}{$\begin{array}{l}\text { Sirakaraağaçlar Stream, Sinop (Karslı and Aral, } \\
\text { 2010) }\end{array}$} & \multirow[t]{2}{*}{ A. danfordii } & $\mathrm{F}$ & 233 & 0.0135 & 3.179 & 0.989 \\
\hline & & M & 219 & 0.0144 & 3.149 & 0.983 \\
\hline \multirow[t]{2}{*}{ Shalamzar Spring, Iran (Alavi-Yeganeh et al., 2011) } & \multirow[t]{2}{*}{ A. vladykovi } & $\mathrm{F}$ & 78 & 0.00830 & 3.482 & 0.989 \\
\hline & & M & 41 & 0.01070 & 3.276 & 0.962 \\
\hline \multirow[t]{2}{*}{ Ayata Lake, Algeria (Guezi et al., 2017) } & \multirow[t]{2}{*}{ A. fasciatus } & $\mathrm{F}$ & - & 0.013 & 2.848 & 0.861 \\
\hline & & M & - & 0.013 & 2.809 & 0.863 \\
\hline \multirow{2}{*}{$\begin{array}{l}\text { Etolikon Lagoon, Greece (Leonardos and Sinis, } \\
\text { 1999) }\end{array}$} & \multirow[t]{2}{*}{ A. fasciatus } & $\mathrm{F}$ & 160 & 0.00826 & 3.220 & 0.970 \\
\hline & & M & 137 & 0.00758 & 3.260 & 0.980 \\
\hline \multirow{2}{*}{$\begin{array}{l}\text { Hirfanlı Reservoir (Yoğurtçuoğlu and Ekmekçi, } \\
\text { 2013) }\end{array}$} & \multirow[t]{2}{*}{ A. danfordii } & $\mathrm{F}$ & 1224 & 0.00003 & 3.460 & 0.978 \\
\hline & & M & 1010 & 0.00004 & 3.450 & 0.964 \\
\hline \multirow[t]{2}{*}{ Kırkgöz Spring, Antalya (Güçlü and Küçük, 2008) } & \multirow{2}{*}{$\begin{array}{l}\text { P. similis (A. } \\
\text { mento) }\end{array}$} & $\mathrm{F}$ & 342 & 0.0702 & 2.225 & 0.846 \\
\hline & & M & 312 & 0.0568 & 2.403 & 0.878 \\
\hline \multirow[t]{2}{*}{ Seyhan Reservoir, Adana (Ergüden, 2020) } & \multirow{2}{*}{$\begin{array}{l}P . \text { similis }(A . \\
\text { mento) }\end{array}$} & $\mathrm{F}$ & 318 & 0.00081 & 2.464 & 0.993 \\
\hline & & M & 516 & 0.00052 & 2.635 & 0.982 \\
\hline \multirow[t]{2}{*}{ Mamasın Reservoir* } & \multirow{2}{*}{$\begin{array}{l}P . \text { similis (A. } \\
\text { mento) }\end{array}$} & $\mathrm{F}$ & 31 & 0.011 & 3.589 & 0.982 \\
\hline & & M & 75 & 0.015 & 3.406 & 0.939 \\
\hline \multirow[t]{2}{*}{ Seyhan Reservoir* } & \multirow{2}{*}{$\begin{array}{l}\text { P. similis (A. } \\
\text { mento) }\end{array}$} & $\mathrm{F}$ & 54 & 0.017 & 3.083 & 0.980 \\
\hline & & M & 33 & 0.008 & 3.725 & 0.974 \\
\hline
\end{tabular}

*Present study area.

In this study, LWR parameters in Seyhan Reservoir is similar to A. vladykovi (Alavi-Yeganeh et al., 2011) and A. danfordii (Yoğurtçuoğlu and Ekmekçi, 2013); but different from A. fasciatus (Guezi et al., 2017) and P. similis (Güçlü and Küçük, 2008). These situations may be caused by reproduction periods and the habitat differences.

In the study in Etolikon Lagoon, it was found positive allometry for females $(b=3.220)$ and males ( $b=3.260$ ) for A. fasciatus species (Leonardos and Sinis, 1999). In a previous study in Kırkgöz 
Spring (Antalya), it was found negative allometric growth for females ( $b=2.225)$ and males $(b=2.403)$ for P. similis (Güçlü and Küçük, 2008). Accordingly, one another Aphanius species A. fasciatus in Ayata Lake, calculated negative allometric growth for females $(b=2.848)$ and males $(b=2.809)$ (Guezi et al., 2017).

In the previous study in Seyhan Reservoir, the LWR parameters were determined as $\mathrm{a}=0.00081, \mathrm{~b}=2.464, \mathrm{r}=0.993$ in females and $\mathrm{a}=0.00052, \mathrm{~b}=2.635, \mathrm{r}=0.982$ in males (Ergüden, 2020). In the present study, the regression parameters for the same locality were determined as $a=0.017$, $\mathrm{b}=3.083 \mathrm{r}=0.980$ in females, and $\mathrm{a}=0.008, \mathrm{~b}=3.725, \mathrm{r}=0.974$ in males. Both study were highly correlated between length and weight. The present study's $b$ constant was found bigger than the previous study for both sexes. The main reason of the differences might be the sampling period of the species; the previous study samplings was occurred in all seasons (inclusive the winter period); but in the present study sampling was occurred just in May. This situation, might be created some differences in access to food resources and their feeding.

It is famously known that the $b$ constant changes cause of a number of different factors. The most known factors are sex, age, stomach fullness, gonad maturity, fish health and fishing characters (Wootton, 1998). Bagenal and Tesch (1978) remarked that LWRs might be effected by maturity, sex, geographical location and environmental factors. The LWRs constants of a fish population should be attributed to reproduction period, feeding, habitat differences, season period, sampling method etc. (Moutopoulos and Stergiou, 2002). Thus, the differences in the $b$ constant may have been related to the one or more factors mentioned above.

\section{Conclusion and Suggestions}

In the present study, which is an important part of freshwater fish fauna in our country in terms of endemic species $P$. similis's LWRs was obtained. Their IUCN Red List category and criteria is Least Concern, moreover, their current population trend is “decreasing” (IUCN 2020).

Within the current study, $P$. similis specimens were sampled in Mamasin Reservoir for the first time. In addition, the actual study considers the first information on the LWRs of $P$. similis in Mamasin Reservoir of Turkey. The basic information on the LWRs for an established population in Mamasın and Seyhan reservoirs, which would be useful for fish biologists to save their populations in Turkey.

Aphanius species are very important part of Turkey's freshwater's ichthyofauna with their endemic characters (Alagöz Ergüden, 2015). Today, Aphanius genus under a high risk of extinction caused by different factors such as the habitat loss, invasive species and pollution. The best way to save the population of $P$. similis species is to increase the number of scientific studies about them, 
therefore the studies on the species should be increased. As a further study might be about the population structure in the two localities should be investigated. Also, their population structure should be examined. They might be monitoring in the freshwater resources regularly.

\section{Acknowledgments}

This study's samples were collected (as discards samples) in the Ege University Scientific Research Project Commission with BAP-Project No:2015/SÜF/016. This study’s results were not a part of first author's PhD Thesis. We are grateful to the Republic Of Turkey Ministry Of Agriculture And Forestry for the legal permission. We would like to thank TÜBİTAK BIDDEB, which supported the first author with a scholarship during the project.

\section{References}

Alagöz Ergüden, S. (2015). Seyhan Baraj Gölü (Adana)'ndeki Aphanius mento (Heckel, 1843)'nun Baz1 Morfometrik Özellikleri. Düzce Üniversitesi Bilim ve Teknoloji Dergisi, 3, 100-106.

Alagöz Ergüden, S., and Göksu, M. Z. L. (2012). The fish fauna of the Seyhan Dam Lake (Adana). FisheriesSciences.com, 6, 39-52.

Alavi Yeganeh, M. S., Seifabadi, S. J., Keivany, Y., Kazemi, B., and Wallis, G. P. (2011). Comparison of length-weight relationships in different populations and sexes of Iranian thoothcarps. Journal of Ichthyology, 27(6), 1401-1403.

Baensch, H. A., and Riehl, R. (1985). Aquarien atlas. Band 2. Mergus, Verlag für Natur-und Heimtierkunde GmbH, Melle, Germany. 1216 p.

Bagenal, T. B., and Tesch, F. W. (1978). Age and growth. In: Bagenal T.B., editör. Methods for assessment of fish production in fresh waters. 3rd edn. Oxford: Blackwell Scientific Publications, UK. pp. 101-136.

Bardakçı, F., Tatar, N., and Hrbek, T. (2004). Genetic Relationships Between Anatolian Species and Subspecies of Aphanius Nardo, 1827 (Pisces, Cyprinodontiformes) Based on RAPD Markers. Biologia, 59(5), 559-566.

Ergüden, S. A. (2020). Age and growth of iridescent toothcarp Aphanius mento (Heckel, 1843) (Cyprinodontidae) in Seyhan Reservoir (Southeastern Mediterranean, Turkey). Iranian Journal Of Fisheries Sciences, 19(5), 2340-2353. doi: 10.22092/ijfs.2019.118929

Freyhof, J., and Yoğurtçuoğlu, B. (2020). A proposal for a new generic structure of the killifish family Aphaniidae, with the description of Aphaniops teimorii (Teleostei: Cyprinodontiformes). Zootaxa, 4810(3), 421-451.

Guezi, R., Chaoui, L., and Kara, H. (2017). Life history of the Mediterranean killifish Aphanius fasciatus in brackish water habitat of Algerian low Sahara. Environmental Biology of Fishes, 100(5), 481-491.

Güçlü, S. S. (2003). Kırkgöz Kaynağı (Antalya)'nda Yaşayan Aphanius mento (Heckel in: Russegger, 1843)'nun Beslenme, Büyüme ve Üreme Özelliklerinin Araştırılması. Yüksek Lisans Tezi, Süleyman Demirel Üniversitesi, Isparta.

Güçlü, S. S. (2012). Population structure of Killifish, Aphanius anatoliae (Cyprinodontidae) endemic to Anatolia in Lake Eğirdir-Isparta (Turkey). Iranian Journal of Fisheries Sciences, 11, 786-795.

Güçlü, S. S., and Küçük, F. (2008). Population age, sex structure, growth and diet of Aphanius mento Heckel in: Russegger, 1843 (Cyprinodontidae: Teleostei), at Kırkgöz Spring, Antalya-Türkiye. Turkish Journal of Fisheries and Aquatic Sciences, 8, 269-274.

Güçlü, S. S., and Küçük, F. (2011). Reproductive biology of Aphanius mento (Heckel in: Russeger, 1843) (Osteichthyes: Cyprinodontidae) in Kırkgöz Spring (Antalya-Turkey). Turkish Journal of Fisheries and Aquatic Sciences, 11, 323-327. 
Güçlü, S. S., Turna, İ. İ., Güçlü, Z., and Gülle, İ. (2007). Population Structure and Growth of Aphanius anatoliae sureyanus Neu, 1937 (Osteichthyes: Cyprinodontidae), Endemic to Burdur Lake, Turkey. Zoology in the Middle East, 41, 63-69.

Hrbek, T., Küçük, F., Frickey, T., Stölting, K. N., Wildekamp, R. H., and Meyer, A. (2002). Molecular phylogeny and historical biogeography of the Aphanius (Pisces, Cyprinodontiformes) species complex of central Anatolia, Turkey. Molecular Phylogenetics and Evolution, 25, 125-137.

Hrbek, T., and Meyer, A. (2003). Closing of the Tethys Sea and the Phylogeny of Eurasian Killifishes (Cyprinodontiformes: Cyprinodontidae). Journal of Evolutionary Biology, 16, 17-36.

Hrbek, T., and Wildekamp, R. H. (2003). Aphanius villwocki, a New Species from the Sakarya River Basin of Central Anatolian Plain, Turkey (Teleostei: Cyprinodontiformes). Ichthyological Exploration of Freshwaters, 14(2), 137-144.

Huber, J. H. (1996). Killi-Data 1996. Updated checklist of taxonomic names, collecting localities and bibliographic references of oviparous Cyprinodont fishes (Atherinomorpha, Pisces). Société Française d'Ichtyologie, Muséum National d'Histoire Naturelle, Paris, France, 399 p.

IUCN 2020. The IUCN Red List of Threatened Species. Version 2020-2. <https://www.iucnredlist.org> (Erişim Tarihi: 07 Temmuz 2020).

Karsl1, Z., and Aral, O. (2010). Population age, sex structure and growth of Aphanius dandfordii (Boulenger, 1890) to Sirakaraağçlar Stream, Turkey. Journal of Animal and Veterinary Advances, 9(10), 1427-1431.

Kosswig, C. (1955). Zoogeography of the near East. Systematic Zoology, 4, 49-73.

Krupp, F., and Schneider, W. (1989). The fishes of the Jordan River drainage basin and Azraq Oasis. In Fauna of Saudi Arabia, 10, 347-416.

Küçük, F., and İkiz, R. (2004). Antalya Körfezi'ne Dökülen Akarsuların Balık Faunası. E.U. Journal of Fisheries and Aquatic Sciences, 21, (3-4), 287-294.

Leonardos, I., and Sinis, A. (1999). Population age and sex structure of Aphanius fasciatus (Nardo, 1827) (Pisces: Cyprinodontiformes) in the Mesolongi and Etolikon Lagoons (West Greece). Fisheries Research, 40(3), 227-235.

Moutopoulos, D. K., and Stergiou, K. I. (2002). Length-weight and length-length relationships of fish species from the Aegean Sea (Greece). Journal of Applied Ichthyology, 18(3), 200-203. doi:10.1046/j.14390426.2002.00281.x

Pajuelo, J. G., and Lorenzo, J. M. (1998). Population biology of the common pandora Pagellus erythrinus (Pisces: Sparidae) off the Canary Islands. Fisheries Research, 36(2-3), 75-86.

Petrakis, G., and Stergiou K. I. (1995). Weight-length relationships for 33 fish species in Greek waters. Fisheries Research, 21, 465-469.

Pfleiderer, S., Geiger, M., and Herder, F. (2014). Aphanius marassantensis, a new toothcarp from the Kizılırmak drainage in northern Anatolia (Cyprinodontiformes: Cyprinodontidae). Zootaxa, 3887(5), 569-582. doi:10.11646/Zootaxa.3887.5.4

Ricker, W. E. (1973). Linear regressions in fishery research. Journal of the Fisheries Research Board of Canada, 30(3), 409-434. doi:10.1139/f73-072

Sangun, L., Akamca, E., and Akar, M. (2007). Weight-length relationships for 39 fish species from the NorthEastern Mediterranean Coast of Turkey. Turkish Journal of Fisheries and Aquatic Sciences, 7, 3740.

Sezen, S. (2011). Determination of embryological and larval development stages of Aphanius mento (Heckel, 1843) in Kırkgöz Source. MSc Thesis, University of Süleyman Demirel. 40 P (In Turkish).

Tarkan, A. S., Gaygusuz, Ö., Acıpınar, H., Gürsoy, Ç., and Özuluğ, M. (2006). "Length-weight relationship of fishes from the Marmara region (NW-Turkey)". Journal of Applied Ichthyology, 22, 271-273.

Tesch, F. W. (1971). Age and growth. In: Methods for assessment of fish production in fresh waters. W. E. Ricker (Ed.). Blackwell Scientific Publications, Oxford, pp. 99-130.

Villwock, W., and Franz, V. R. (1972). Beitrag zur Kenntnis der Zahnentwicklung bei oviparen Zahnkarpfen der Tribus aphaniini (Pisces, Cyprinodontidae). Inst, Band 80, S. 251-277. Mitteilungen aus dem Hamburgischen Zoologischen Museum und Institut, 68, 135-176.

Wildekamp, R. H. (1993). A World of Killies, Atlas of the Oviparous Cyprinodontiform Fishes of the World, Volume I". The Genera Adamas, Adinia, Aphanius, Aphyoplatys and Aphyosemion Published by the American Killifish Association. Inc., 311p, U.S.A.

Wildekamp, R. H., Küçük, F., Ünlüsayın, M., and Van Neer, W. (1999). Species and Subspecies of the Genus Aphanius Nardo 1897 (Pisces: Cyprinodontidae) in Turkey. Turkish Journal of Zoology, 23, 23-44.

Wootton, R. J. (1998). Ecology of teleost fishes. Kluwer Academic Publishers, Dordrecht, 396 pp. 
Yoğurtçuoğlu, B., and Ekmekçi, F. G. (2013). Life-history traits of Aphanius danfordi (Boulenger, 1890) (Pisces: Cyprinodontidae), endemic to Kizilırmak Basin (Turkey). Journal of Applied Ichthyology, 29, 866-871.

Zar, J. H. (1999). Biostatistical Analysis. 4th Edition. Prentice Hall Inc., Upper Saddle River, New Jersey, 663 pp. 